\title{
Transglutaminase activity during senescence and programmed cell death in the corolla of tobacco (Nicotiana tabacum) flowers
}

\author{
D Serafini-Fracassini" ${ }^{*, 1}$, S Del Duca ${ }^{1}$, F Monti ${ }^{1}$, F Poli ${ }^{1}$, \\ G Sacchetti ${ }^{2}$, AM Bregoli ${ }^{1}$, S Biondi ${ }^{1}$ and M Della Mea ${ }^{1}$ \\ ${ }^{1}$ Dipartimento di Biologia Evoluzionistica Sperimentale, Università di Bologna, \\ Bologna, Italy \\ 2 Dipartimento di Biologia, Sez. di Botanica, Università di Ferrara, Ferrara, Italy \\ * Corresponding author: D Serafini-Fracassini, Dipartimento di Biologia E.S.- \\ Sez. Botanica, Università di Bologna, Via Irnerio 42, Bologna, Italy. \\ Tel: 0039051 2091292; Fax: 0039051 242576; \\ E-mail: serafrac@kaiser.alma.unibo.it
}

Received 9.11.00; revised 31.7.01; accepted 11.9.01

Edited by M Piacentini

\begin{abstract}
Corolla life span of undetached flowers of Nicotiana tabacum was divided into stages from the closed corolla (stage 1) through anthesis (stage 5) to death (stage 9). Senescence began around stage 6 in the proximal part, concomitantly with DNA laddering. Nuclear blebbing, DNA laddering, cell wall modification, decline in protein, water, pigment content and membrane integrity were observed during senescence and PCD. Transglutaminase activity was measured as mono- and bis-derivatives of putrescine (mono-PU; bis-PU) and bis-derivatives of spermidine (bisSD). Bis-derivatives decreased with the progression of senescence, while mono-PU increased during early senescence; derivatives were present in different amounts in the proximal and distal parts of the corolla. In excised flowers, exogenous spermine delayed senescence and PCD, and caused an increase in free and acid-soluble conjugated PA levels. Bis-PU was the most abundant PA-derivative before DNA laddering stage; thereafter, bis-PU generally decreased and mono-PU became the most abundant derivative.

Cell Death and Differentiation (2002) 9, 309-321. DOI: 10.1038/ sj/cdd/4400954
\end{abstract}

Keywords: flower; glutamyl-polyamines; Nicotiana tabacum; programmed cell death; senescence; spermine

Abbreviations: bis-PU, bis-(gamma-glutamyl)-putrescine; bis-SD, bis-(gamma-glutamyl)-spermidine; DAPI, 4,6-diamidino-2-phenylindole; mono-PU, mono-(gamma-glutamyl)-putrescine; PAs, polyamines; PCD, programmed cell death; PMSF, phenylmethylsulphonylfluoride; PU, putrescine; SD, spermidine, SM, spermine; STS, silver thiosulphate; TCA, trichloroacetic acid; TGase, transglutaminase (glutaminyl-peptide gamma-glutamyltransferase)

\section{Introduction}

In plants, free aliphatic polyamines (PAs) have a well established role in the stimulation of cell division, in growth, and in the delay of senescence. They are therefore considered 'juvenility' factors. In fact, when supplied to excised leaves, PAs can temporarily prevent membrane damage, and protein, nucleic acid and chlorophyll degradation. $^{1-4}$ The molecular mechanism underlying this protective role has not yet been completely clarified. PAs in bound form, and in particular those conjugated to specific proteins through the action of a family of $\mathrm{Ca}^{2+}$-dependent transamidating enzymes, the transglutaminases (TGases), also deserve particular attention, as they can affect the conformation and function of the proteins to which they are linked. ${ }^{5}$ The best known role of TGases is to stabilise proteins ${ }^{6}$ by catalysing the formation of cross-linkages between glutaminyl- and lysylresidues, or between glutaminyl-residues and polyamines thus forming mono- or bis-PA derivatives. In the latter case, 'bridges' among proteins can be formed. From such multiple linkages, a large protein net can be produced as described for both plant and animal cells. ${ }^{6-8}$

TGases have a low activity in growing cells, whereas it is well established that enhanced TGase gene expression, protein accumulation and/or activity are associated with animal cell death. In 1987, Fesus and co-workers ${ }^{9}$ published the first study on the involvement of tissue TGase (tTGase) in induced liver hyperplasia. Later on, a clear role for TGases was revealed in the formation of apoptotic bodies $^{10}$ and in many mammalian systems ${ }^{11-17}$ suggesting that TGases are downstream effectors in the later stages of apoptosis. $^{12-15}$ However, tTGase expression also occurs as an early apoptotic event; ${ }^{14}$ indeed tTGase, due to its bifunctional activity as transglutaminase but also as GTPase, can also act as effector in the prevention of cell death. Despite the large body of information accumulated in recent years, many aspects regarding TGase function in apoptosis remain to be elucidated.

TGases are now known to be present also in plants. ${ }^{18-}$ 21 Plant TGases may be involved in growth by cell division, ${ }^{7,22,23}$ in apical growth, ${ }^{24}$ as well as in stress responses. ${ }^{25}$ Evidence for their structural role comes from the identification of some of their substrates, e.g. actin and tubulin $^{24}$ or cell wall proteins, ${ }^{21}$ and through its involvement in the polymerisation of Rubisco. ${ }^{26}$ Different roles for TGase have been proposed in chloroplasts ${ }^{27}$ and mitochondria. $^{28}$

In contrast to the considerable number of reports concerning TGase in dying animal cells, no information is available regarding this enzyme family during $P C D$ in plants. Indeed, knowledge about PCD in plants lags far behind that of animal PCD. ${ }^{29}$ Most of the studies are 
focused on the hypersensitive response to pathogens or stress-induced cell death. ${ }^{30-32}$ A few studies have dealt with leaf senescence and death. ${ }^{33}$ Another system of great interest is the flower, in which both reproductive organs and petals undergo highly reproducible morphological and physiological modifications during their life span, including PCD. ${ }^{34-36}$ Petals have a vexillary role in attracting insects for pollination. In most flowers, pollination acts as a signal leading to disposal of the petals, even though in short-lived flowers senescence is controlled by an independent endogenous programme completed by cell death. ${ }^{37}$ Plant hormones such as ethylene and its immediate precursor, 1aminocyclopropane-1-carboxylic acid, cytokinins, and abscisic acid as well as other factors seem to regulate petal senescence. $^{36,38,39}$ In fact, the gene 'defender against apoptotic death', Dad-1, is an evolutionarily conserved inhibitor of animal PCD which is downregulated by ethylene. Its expression declines dramatically in pea petals after anthesis, in relation to an increase in DNA fragmentation. 40

Little information is available on the relationship between free PAs and flower senescence. ${ }^{36.41}$ In order to address the question as to the involvement of protein-conjugated PAs in plant senescence and PCD, in the present study the corolla of Nicotiana tabacum flowers was selected as a model system because it offers several advantages: ${ }^{42}$ it senesces in a rapid and predictable manner without the need for pollination, it is large, and has a rather homogeneous histological composition. Senescence and death were studied in planta on undetached flowers, where both events occur naturally without the need to induce them artificially. The different stages of maturation, senescence and death were established macroscopically based on morphological parameters. The timing and localisation of the most characteristic events were evaluated by biochemical and physiological analyses as well as cytological observations. TGase activity, as revealed by the formation of glutamyl derivatives, was assayed in the various stages and in different parts of the corolla. In order to evaluate the anti-senescence effects of PAs, detached flowers were treated with exogenous spermine (SM) and, for comparative purposes, with an inhibitor of ethylene action, silver thiosulphate (STS), previously shown to delay senescence in flowers. ${ }^{37,43}$ In order to establish a correlation between TGase activity and rate of senescence, glutamyl derivatives of PAs were monitored.

\section{Results}

\section{Entire corolla of undetached flowers}

The morphological and physiological characteristics of the corolla of undetached flowers were analyzed in order to identify the stages of development and senescence; the time-course of senescence and PCD was monitored on the basis of several biochemical parameters after extraction of the whole corolla.

Morphological observations The developmental stages of the flower and the relative morphological characteristics of the corolla are shown in Figure 1. Based on macroscopical observations, the following stages were identified:

Stages 1-2: Developing flower. The corolla is green, open and teeth are erect.

Stages 3-4: Developing flower. The corolla is still mainly green but the very distal part is turning pink. Teeth are opening outwards.

Stage 5: Anthesis. The distal part of the corolla has an intense pink colour while the proximal portion is green. The teeth are patent and form an angle of about $90^{\circ}$ with the lower tubular part of the corolla.

Stage 6: Transition stage. Similar to the previous stage, but the corolla presents an intense pigmentation.

Stage 7: Senescence. The corolla presents an appreciable loss of turgidity and colour. The very basal part exhibits a brown ring that marks the future abscission zone.

Stage 8: Late senescence. Teeth curl inwards and become brown. The corolla is drying.

Stage 9: Death. The corolla is dry and de-pigmented. It is easily detached whole from the receptacle.

Stage 10: The corolla is completely papyraceous and brown; it drops spontaneously.

Biochemical indicators of senescence and PCD Percentage water content of the corolla increased slightly up to stage 6 and then decreased, showing that wilting had begun (Figure 2A). Due to water loss, the data reported below are expressed on a dry weight basis.

Conductivity, which is an index of membrane integrity, remained low until stage $5(100 \%)$, increased slowly till stage 7 and much more sharply, and significantly, thereafter (Figure 2B).

The pink colour, due to anthocyanin content, increased until stage 6 and decreased thereafter with a statistically significant trend (Figure 2C). Chlorophyll content, measured as phaeophytin after acidic treatment, significantly decreased especially between stages 5 and 6 (Figure 2D).

Total protein concentration showed a maximum at stage 6 and then significantly decreased (Figure 2E).

Protease activity began to increase at stage 5 , peaked abruptly and significantly at stage 6 , and then dropped at the later stages (Figure 2F). Inhibitors of serine- and cysteine-proteases were used in assays performed with extracts of flowers at stage 6 in order to characterise the type of protease activity (inset Figure 2G). Phenylmethylsulphonylfluoride (PMSF) had a very scarce effect, whereas leupeptin significantly reduced protease activity to $30 \%$ of control values, suggesting that cysteine-proteases were probably active.

The agarose gel analysis showed that nuclear DNA was still undigested at stage 5; DNA laddering began at stage 6 , and continued in the subsequent stages, as shown by comparison with standard digested DNA (Figure 3). At stages 6 and 7, the corolla was cut into a proximal and a distal part (see below), and their respective DNA patterns also shown in Figure 3.

Transglutaminase activity TGase activity was measured as the recovery of total labelled (gamma-glutamyl)-derivatives of PAs (Figure 4A). Mono-(gamma-glutamyl)-putrescine (mono$P U)$, bis-(gamma-glutamyl)-putrescine (bis-PU) and 

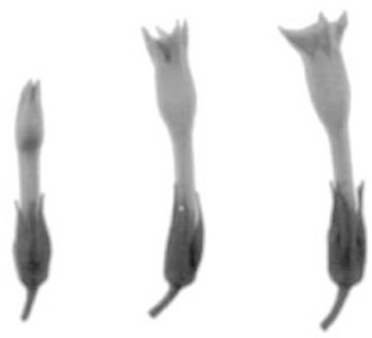

2

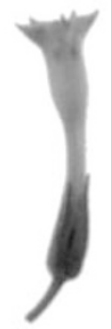

4

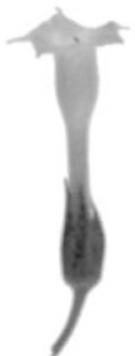

5

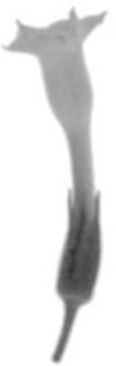

6

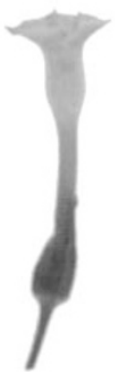

7

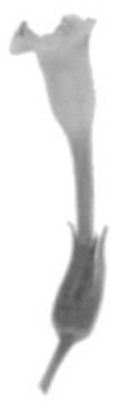

8

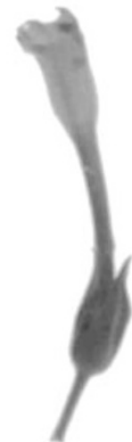

9

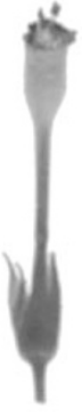

10

Figure 1 Developmental stages of the flower of Nicotiana tabacum. Stages 1-4, developing flower. Stage 5, anthesis. Stage 6, transition stage. Stage 7, senescence. Stage 8 , late senescence. Stages $9-10$, death
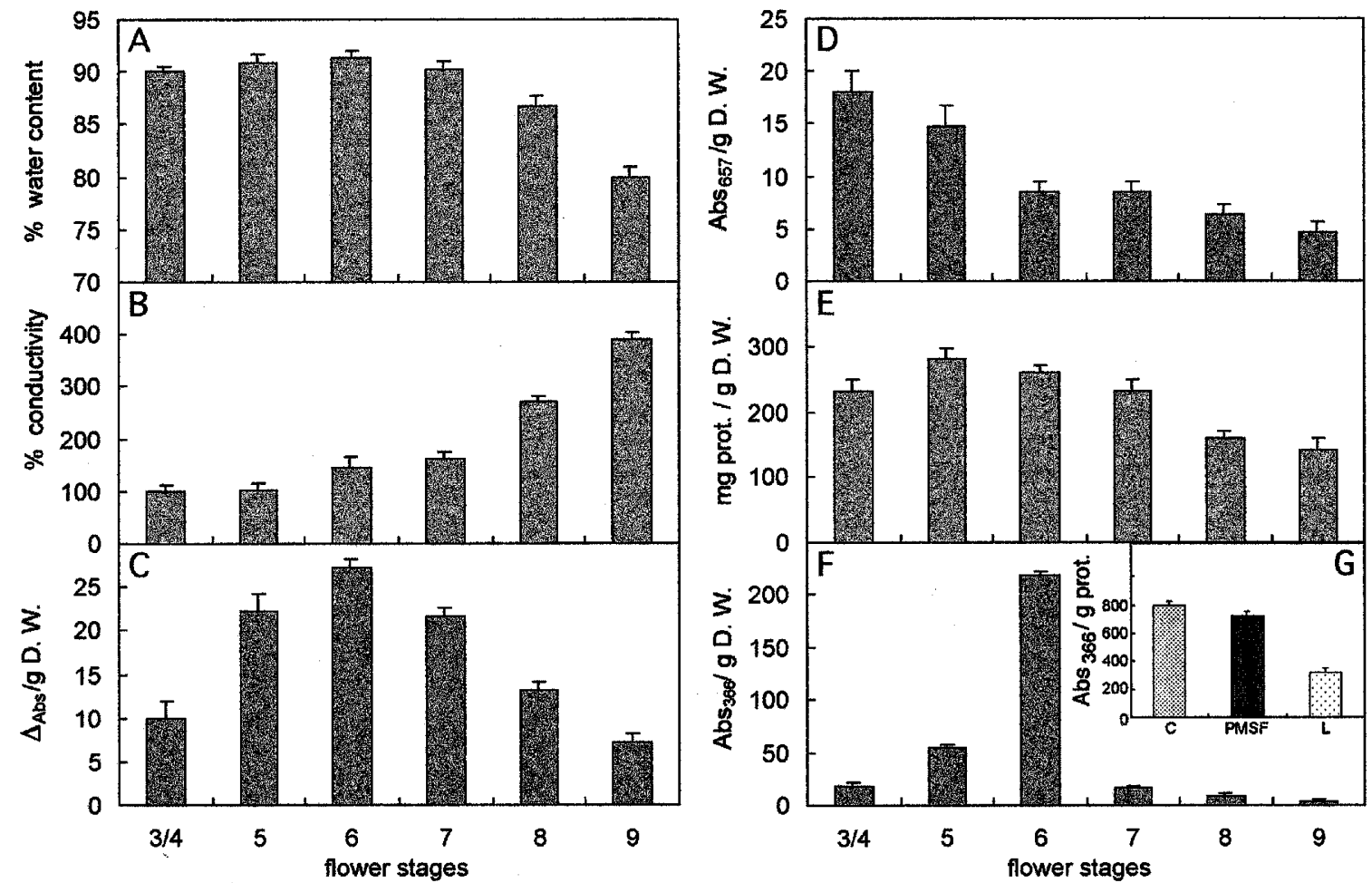

Figure 2 Parameters used to monitor corolla senescence at the stages indicated in Figure 1. (A) Percentage water, on the basis of total fresh weight. (B) Conductivity (value at stage 3-4=100). (C) Anthocyanin content. (D) Phaeophytin content. (E) Total protein content. (F) Protease activity. C $-\mathbf{F}$ are expressed on a dry weight basis. (G) Effect of $1 \mathrm{mM}$ PMSF or $0.1 \mathrm{mM}$ leupeptin on the protease activity of corolla extracts from flowers at stage 6 . Student's $t$-test for the correlation coefficient of the parameters as a function of flower stages was significant at $P<0.05$ for $(\mathbf{B}-\mathbf{E})$. In $(\mathbf{F})$ the differences between the mean value at stage 6 and the other values was significant at $P<0.01$. In $(\mathbf{G})$ the difference between the mean values of the leupeptin-treated and untreated samples was significant at $P<0.05$

-spermidine (bis-SD) were detected in corolla extracts (Figure 4B). Bis-PU was the most abundant product at all stages, and its content showed a statistically significant decreasing trend with increasing age of the corolla (stages 3 to 8 ). The amount of bis-SD also exhibited a similar decreasing trend, in contrast with mono-PU which significantly increased at stage 7 .

To evaluate the $\mathrm{Ca}^{2+}$-dependence, TGase activity, in this case evaluated after TCA precipitation, was checked in the presence of different $\mathrm{Ca}^{2+}$ concentrations. Results show that activity was stimulated at concentrations above
$0.25 \mathrm{mM}$, and inhibited by EGTA at concentrations above $10 \mathrm{mM}$ (Figure 5). The residual activity, detected at high EGTA concentrations, is to be considered $\mathrm{Ca}^{2+}$-independent, and indeed possibly not due to TGase.

\section{Proximal vs distal parts of the corolla of the undetached flower}

Having established that the whole corolla at stages 6 and 7 revealed the first signs of the occurrence of the main PCD 
st ages

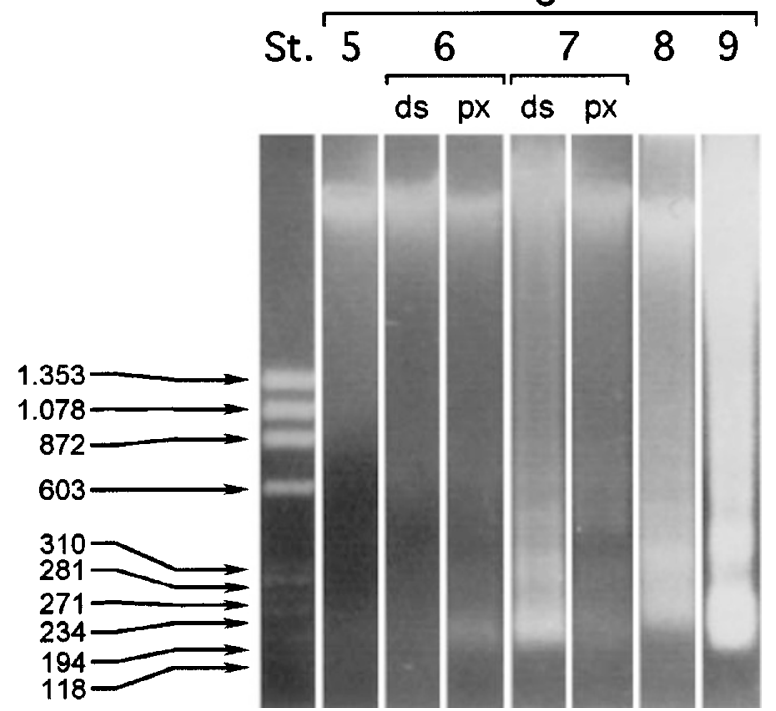

Figure 3 DNA laddering in corolla cells of flowers at stages 5-9. DNA was analyzed by agarose gel electrophoresis (1.4\% agarose) and staining with ethidium bromide. St: apoptotic DNA standard, arrows indicate the $\mathrm{kb}$. $d s=$ distal part of the corolla; $p x=$ proximal part of the corolla

events, the latter were monitored separately in the proximal and distal parts of the corolla in order to localise their onset. Thus, the corolla was transversely dissected into two halves (same length, but different weight) and microscopic observations were performed on their nuclei and cell walls. In addition, both parts were extracted separately for further biochemical analyses.

Microscopical observations The epidermis of the corolla of flowers at stages 5, 6 and 7 was peeled off and immediately observed under the microscope in order to check for autofluorescence of the cell walls at $436 \mathrm{~nm}$. The same parts of the corolla were stained with DAPI and observed under UV light at $365 \mathrm{~nm}$. At stage 5, used as non senescent control, no appreciable differences between the proximal and distal parts were visible: cell walls were poorly autofluorescent and nuclei were spherical (see Figure 6A, C, E). At stage 6, the cell walls of the epidermis from the distal part of the corolla were still hardly visible, whereas those of the proximal portion were markedly autofluorescent, (Figure 6A, B). In the distal part, nuclei of DAPI-stained cells were, as in the previous stage, spherical (Figure 6C, E), whereas in the proximal one, blebbing of nuclei was frequent and some nuclear fragmentation also occurred (Figure 6D, F). Cell walls were not visible in the distal portion, but were markedly stained in the proximal one (Figure 6C, D, E, F). At stage 7, both parts of the corolla presented the same characteristics as the proximal part of stage- 6 flowers (not shown). By staining cells with toluidine blue, the same nuclear features and signs of cytoplasm coagulation were visible (not shown).

Biochemical indicators of senescence and PCD Water loss first became evident in the proximal part of stage-7 flowers. At stage 8 , water content further decreased, especially in the
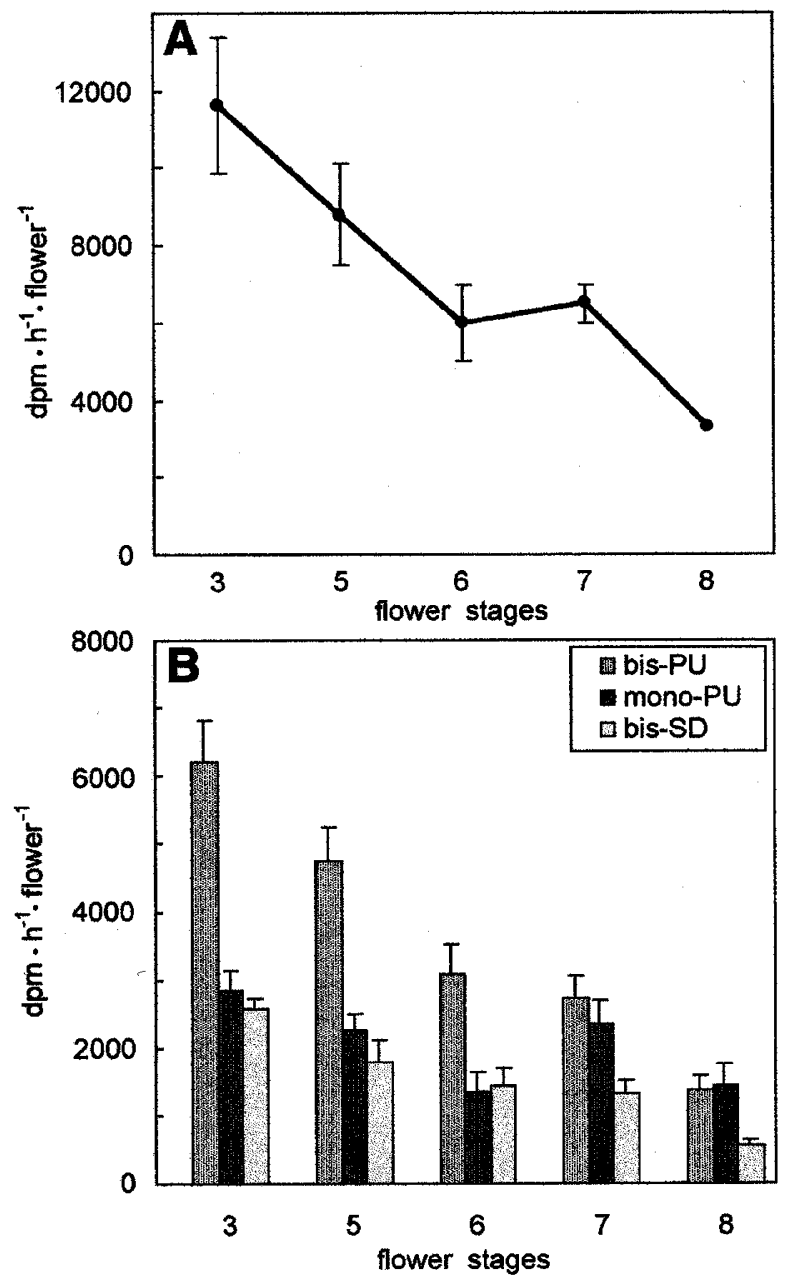

Figure 4 Transglutaminase activity (measured, on the basis of the Lorand assay, as total amount of glutamyl-derivatives) of the corolla of flowers at stages 3-8 (A). Labelled glutamyl-PAs (bis-PU, mono-PU, bis-SD) (B) were detected by HPLC after incubation of corolla extracts with $\left[{ }^{3} \mathrm{H}\right]$ PU. Student's $t$ test for the correlation coefficient of the bis-PU and bis-SD values as a function of flower stages was significant at $P<0.05$. (B), whereas mono-PU did not have a significantly decreasing trend; the mean value for mono-PU at stage 7 was significantly different from its mean value at stage 6 at $P<0.05$

proximal part (data not shown). Total protein concentration was considerably (about $70 \%$ ) lower in the proximal part of the corolla than in the distal one, especially at stage 6 . At stage 7 , the distal portion also underwent a considerable decline (by about $30 \%$ ) in protein content (data not shown). The distal portion at stage 6 exhibited an almost twofold higher protease activity than the proximal one (data not shown). Nuclear DNA laddering was weak but visible both at stages 6 and 7 in the proximal part of the corolla, whereas in the distal one laddering became evident only at stage 7 (Figure 3).

Transglutaminase activity At stage 6, the amount of glutamyl-derivatives was not significantly different in the distal and proximal parts of the corolla. In both portions, bisPU was the most abundant, followed by mono-PU and bis-SD in that order. On the contrary, at stage 7 , the concentration of 
conjugated PAs was much higher in the proximal part (data not shown).

\section{Corolla of excised flowers}

Flowers at anthesis (stage 5) were excised and treated with $5 \mathrm{mM} \mathrm{SM}$, and compared with either $0.25 \mathrm{mM} \mathrm{STS}$ or water

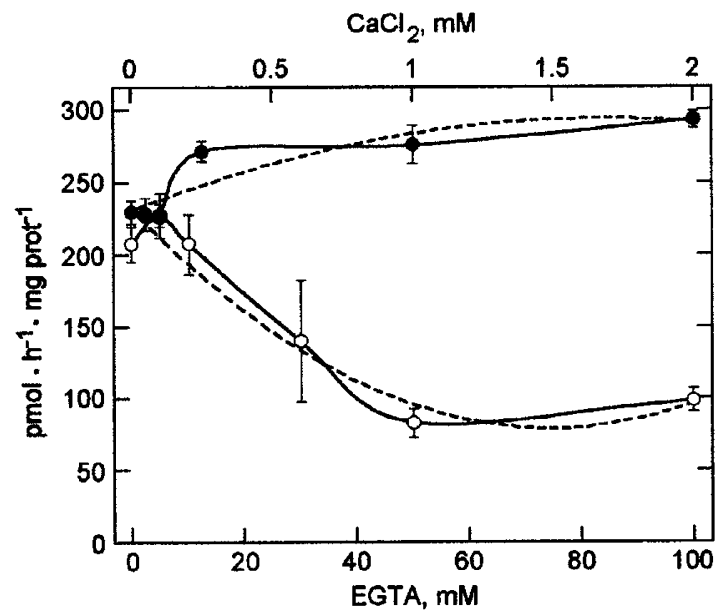

Figure 5 Transglutaminase activity (measured on the basis of the Lorand assay as TCA pelletable radioactivity) as a function of $\mathrm{CaCl}_{2}$ and EGTA supply to the assay mixture. EGTA was preincubated for $10 \mathrm{~min}$. According to Student's $t$-test, the correlation coefficient of the TGase activity was significant for increasing $\mathrm{CaCl}_{2}$ and EGTA concentrations (respectively $P<0.05$ and $<0.01$ ). The mean values for $100 \mathrm{mM} E G T A$ and $2 \mathrm{mM} \mathrm{CaCl}_{2}$ were significantly different from each other as well as from untreated controls $(P<0.05)$ controls. Exogenously supplied SD and PU were also assayed but were less active in delaying senescence (data not shown).

Macroscopical and biochemical indicators of senescence and $P C D$ The morphological stages reached in relation to time after excision are reported in Table 1. At the concentrations tested, SM and STS slowed down flower senescence. In fact, after $48 \mathrm{~h}, 50 \%$ of the untreated flowers were at stage 6 (early senescence) and $50 \%$ at stage 7 (senescence), whereas $80 \%$ of STS-treated and $70 \%$ of SM-treated ones were still at stage 5 . The rest ( 20 and $30 \%$, respectively) presented symptoms of early senescence. After $70 \mathrm{~h}$, water controls were dying or dead (stages 8 and 9), whereas most of the STS-treated flowers were still in the early senescence stage.

Anthocyanin content significantly decreased between excision $(0 \mathrm{~h})$ and $70 \mathrm{~h}$ in corollas of untreated flowers,

Table 1 Percentage of flowers at the different stages after treatment with $5 \mathrm{mM}$ SM, $0.25 \mathrm{mM}$ STS or water $(C)$ for the hours indicated. Flowers were excised at stage 5 and their pedicel immersed in the above solutions

\begin{tabular}{lcccccc}
\hline $\begin{array}{l}\text { Hours } \\
\text { from } \\
\text { excision }\end{array}$ & Treatment & $\begin{array}{c}\text { Stage } \\
\mathbf{5}\end{array}$ & $\begin{array}{c}\text { Stage } \\
\mathbf{6}\end{array}$ & $\begin{array}{c}\text { Stage } \\
\mathbf{7}\end{array}$ & $\begin{array}{c}\text { Stage } \\
\mathbf{8}\end{array}$ & $\begin{array}{c}\text { Stage } \\
\mathbf{9}\end{array}$ \\
\hline 24 & C & $90 \%$ & $10 \%$ & - & - & - \\
& $0.25 \mathrm{mM} \mathrm{STS}$ & $100 \%$ & - & - & - & - \\
48 & $5 \mathrm{mM} \mathrm{SM}$ & $90 \%$ & $10 \%$ & - & - & - \\
& C & - & $50 \%$ & $50 \%$ & - & - \\
& $0.25 \mathrm{mM} \mathrm{STS}$ & $80 \%$ & $20 \%$ & - & - & - \\
70 & $5 \mathrm{mM} \mathrm{SM}$ & $70 \%$ & $30 \%$ & - & - & - \\
& C & - & - & - & $80 \%$ & $20 \%$ \\
& $0.25 \mathrm{mM}$ STS & - & $80 \%$ & $20 \%$ & - & - \\
\hline
\end{tabular}

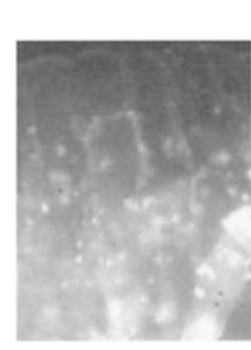

A

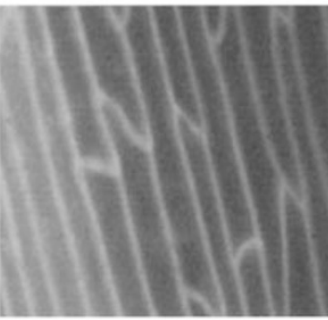

$\mathrm{B}$

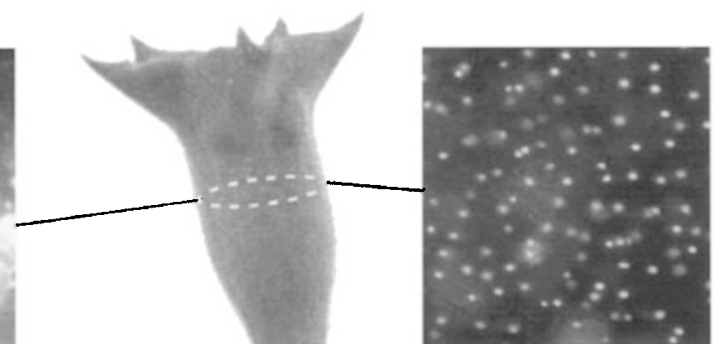

C

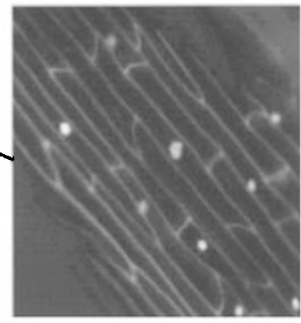

D

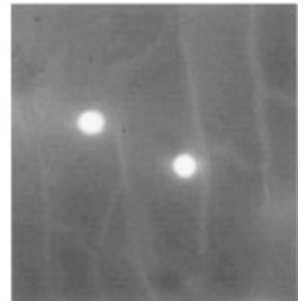

E

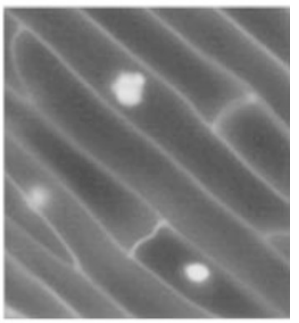

F

Figure 6 Nuclei and cell walls in the proximal (B, D, F) and distal parts (A, C, E) of the corolla of flowers at stage 6. (A, B) Autofluorescence of the cell walls observed under UV-light at $436 \mathrm{~nm}$. (C-F) DAPI-stained cells observed under UV-light at $365 \mathrm{~nm}$ 
whereas it significantly increased in SM- and STS-treated ones (Figure 7A, $A^{\prime}$ ). Phaeophytin content decreased significantly and to the same extent both in controls and treated flowers (Figure 7B, $\mathrm{B}^{\prime}$ ). Total protein content in untreated controls decreased markedly only $70 \mathrm{~h}$ after excision, and was not significantly different from that of SMand STS-treated flowers (Figure $7 \mathrm{C}, \mathrm{C}^{\prime}$ ). Protease activity showed a significant increase at 24 and $48 \mathrm{~h}$ in SM- and STS-treated flowers, respectively (Figure 7D, D').

DNA laddering was evident in corolla cells of untreated flowers already $24 \mathrm{~h}$ after excision; in SM-treated flowers this event was observed only after $48 \mathrm{~h}$, while in STStreated ones, DNA laddering was even more delayed, as it occurred between 48 and $70 \mathrm{~h}$ (Figure 8).

Polyamine content As treatment with SM was likely to affect the cellular content of this PA as well as that of its metabolic derivatives, free and TCA-soluble conjugated PAs were measured in untreated controls and SM-treated flowers. Free PA concentration was stable in untreated controls, whereas free SM content significantly increased several-fold in SM-treated flowers at $24 \mathrm{~h}$ and even more so at $48 \mathrm{~h}$

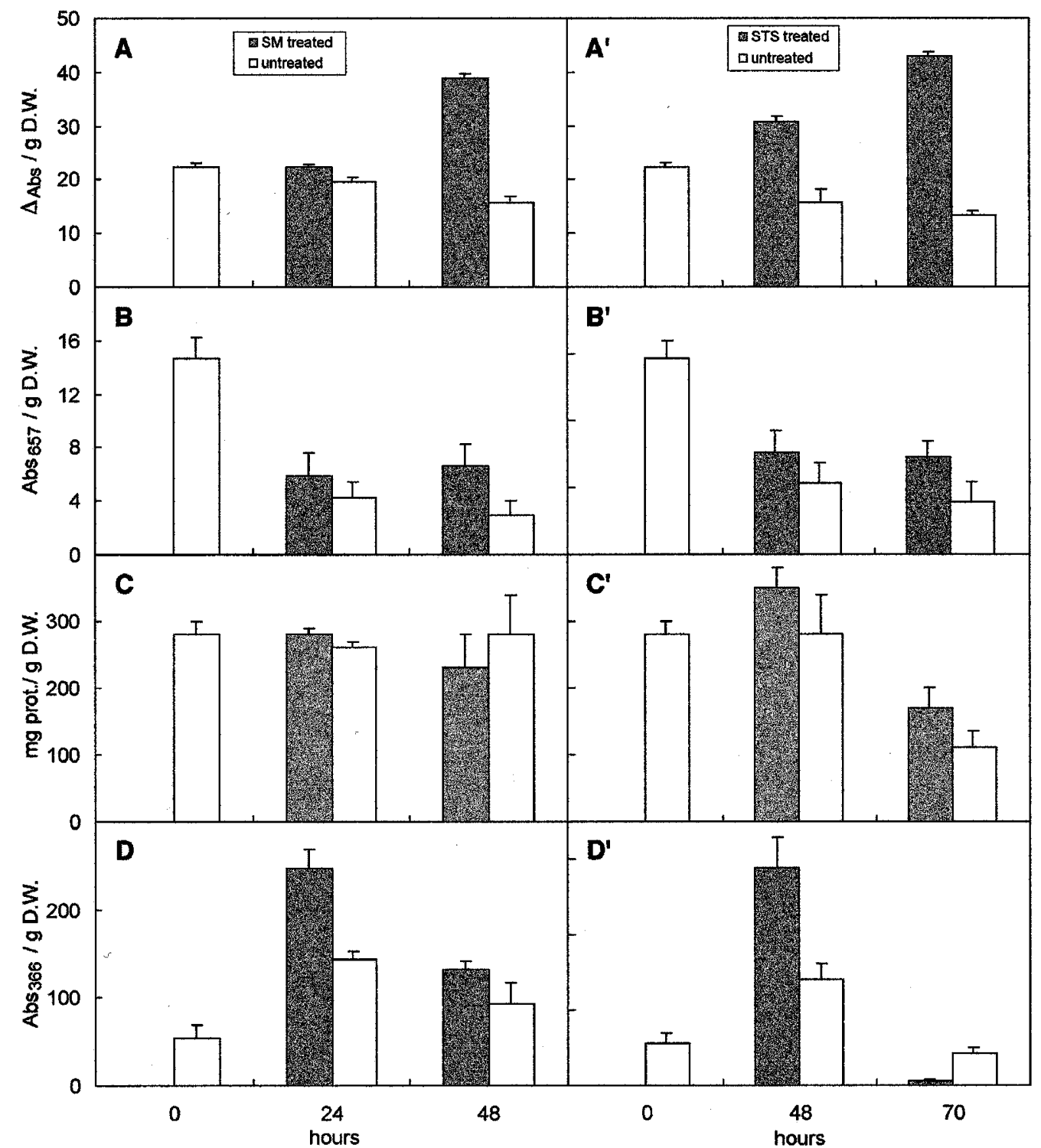

Figure 7 Parameters used to monitor the senescence in the corolla of flowers excised at stage 5. Flowers were either untreated (white bars) or treated (black bars) with $5 \mathrm{mM} \mathrm{SM}(\mathbf{A}-\mathbf{D})$ or $0.25 \mathrm{mM} \mathrm{STS}\left(\mathbf{A}^{\prime}, \mathbf{B}^{\prime}, \mathbf{C}^{\prime}, \mathbf{D}^{\prime}\right)$ for the hours indicated. $\left(\mathbf{A}, \mathbf{A}^{\prime}\right)$ Anthocyanin content. The mean values of samples treated with SM and STS were significantly different (at least $P<0.05$ ) from their untreated controls at 48 and at 48 and $70 \mathrm{~h}$ respectively. The mean values at 48 and $70 \mathrm{~h}$ respectively were significantly different from those at $0 \mathrm{~h}$ (at least $P<0.05)$. (B, B') Phaeophytin content. The mean values of samples treated with SM and STS were not significantly different from their untreated controls; their values at 0 and $24 \mathrm{~h}$, and at 0 and $48 \mathrm{~h}$ were significantly different (at least $P<0.05)$. (C, C') Protein content. The mean values of samples treated with SM and STS were not significantly different (at least $P<0.05$ ) from their untreated controls. (D, D') Protease activity. For STS samples values were significantly different (at least $P<0.05$ ) from their untreated control only at $70 \mathrm{~h}$. The increases between 0 and $24 \mathrm{~h}$ for SM-treated and between 0 and $48 \mathrm{~h}$ for STS-treated samples were significant $(P<0.05)$. All measurements are referred to dry weight 


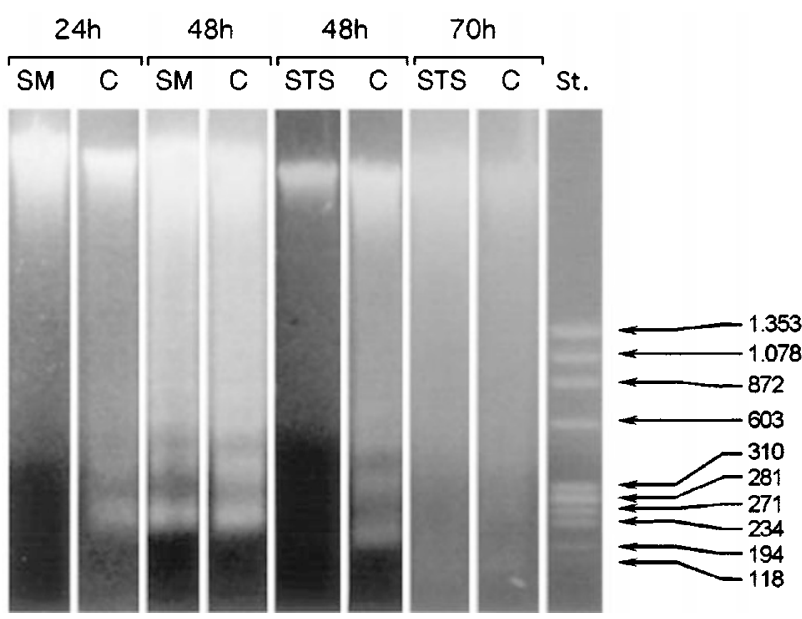

Figure 8 DNA laddering in corolla cells of flowers excised at stage 5 , untreated $(C)$ or treated with $5 \mathrm{mM} \mathrm{SM}$ or $0.25 \mathrm{mM}$ STS for the hours indicated DNA was analysed by agarose gel electrophoresis (1.4\% agarose) and staining with ethidium bromide. St: apoptotic DNA standard, arrows indicate the $\mathrm{kb}$

(Figure 9C). Free $\mathrm{PU}$ was also more abundant than in untreated controls at $24 \mathrm{~h}$ (Figure 9A). TCA-soluble conjugated PAs constituted most of the total PA pool in tobacco flowers, as also previously observed. ${ }^{44}$ Their levels were also rather constant, except conjugated SD which significantly increased between 24 and $48 \mathrm{~h}$ in untreated flowers (Figure 9A', B', $C^{\prime}$ ). SM and SD conjugates were considerably higher in SM-treated flowers compared with untreated ones, the differences being again more conspicuous at $24 \mathrm{~h}$, when SD and SM conjugates were $200 \%$ of controls.

Transglutaminase activity The biochemical parameters described above, and especially DNA laddering, clearly showed that flowers undergo senescence after different time spans. Therefore, in order to compare the TGase activity of flowers at the same physiological stage, DNA laddering was taken as an index of the beginning of senescence; the relative amount of the three glutamylderivatives determined before and after the occurrence of this event (pre-DNA $A_{1}$ and post-DNA $A_{1}$ ), are reported in Figure $10 \mathrm{~A}, \mathrm{~B}, \mathrm{C}$. In all cases, namely in SM- or STS-treated and in untreated corollas, mono-PU levels were significantly different in pre-DNA, and post-DNA $A_{1}$ states; bis-PU levels were also different in the two conditions (STS-treated and untreated control).

Glutamyl-derivatives of SM were undetectable using this in vitro TGase assay. This could be due to the fact that the amount of SM synthesised from labelled PU during the assay is very small; in SM-treated flowers, it could also be due to the dilution effect caused by the large amount of unlabelled SM taken up. In order to check if SM incorporation into conjugated forms could take place in vivo, $\left[{ }^{14} \mathrm{C}\right] \mathrm{SM}$ was supplied to the medium in which the pedicels were immersed. Mono-glutamyl SM was detectable in corolla extracts at $24 \mathrm{~h}$, and its content doubled at $48 \mathrm{~h}$ (data not shown).

\section{Discussion}

\section{Corolla of undetached flowers}

The different morpho-functional parameters analyzed in the present study (nuclear blebbing, DNA laddering, cell wall modification, protein content, loss of membrane integrity, decrease in water content and in pigments) allowed us to evaluate the timing and localisation of the onset of corolla senescence and cell death. Senescence is a gradual event which begins around stage 6 and it is completed by death at stage 9. PCD begins in the proximal part of the corolla (where its abscission will eventually take place) and then the entire corolla dehydrates and dies.

Whereas protein content decreases gradually during senescence, proteases, detected by the in vitro method used here, are particularly active only during a short period around stage 6 . However, their in vivo activity could be different than that assayed in vitro in relation to cellular $\mathrm{pH}$ and/or compartmentation. In fact, there does not seem to be a strict correlation between in vitro protease activity and total protein pool size; alternatively, proteases may hydrolyse only specific proteins. The role of these proteases during PCD remains to be further investigated. Cysteine-proteases have been suggested to be good candidates for cell death initiation also in plants. ${ }^{29}$ Caspases belong to this enzyme family and are well known to have a relevant role in animal apoptosis, whereas only recently the presence and activity of caspase-like enzymes have been reported in plants, including tobacco leaves, ${ }^{45}$ in relation to cell death. ${ }^{46,47}$

A relationship exists between caspases and TGase during animal PCD: the latter enzyme is one of the substrates of caspases during lymphoid cell apoptosis. ${ }^{48}$ Moreover, caspases cleave several proteins which also undergo tTGase-catalysed post-translational modifications during apoptosis. ${ }^{16}$

In the present work, TGase activity was evaluated on the basis of the glutamyl-derivatives produced. This approach provides unequivocal evidence that $\mathrm{PA}$ conjugation is mediated by a TGase, and avoids misinterpretations as to the extent of TGase activity as occurs with other methods. This is also supported by the $\mathrm{Ca}^{2+}$-dependence of the activity. Results show that PU supplied in the assay medium is conjugated as such but also metabolised to $\mathrm{SD}$, and that the latter is conjugated by the enzyme to give bis-SD in an amount which is comparable to that of conjugated PU. Compared with the concentration of exogenously supplied PU, the amount of endogenous PU and $S D$ in the flower extract is negligible.

In the present plant system, bis-PU was the most abundant PA-derivative except in late senescence. The bis-PU and bis-SD levels showed a significant decreasing trend with increasing corolla age, whereas mono-PU significantly increased at stage 7 . The mono-PU/bis-SD ratio ranged around 1 and increased starting from stage 7 , when senescence is already evident and dehydration sets in. A similar result was observed also in detached flowers, confirming that the relative proportion among the three derivatives is different in non-senescent and senescent corollas. 
FREE POLYAMINES

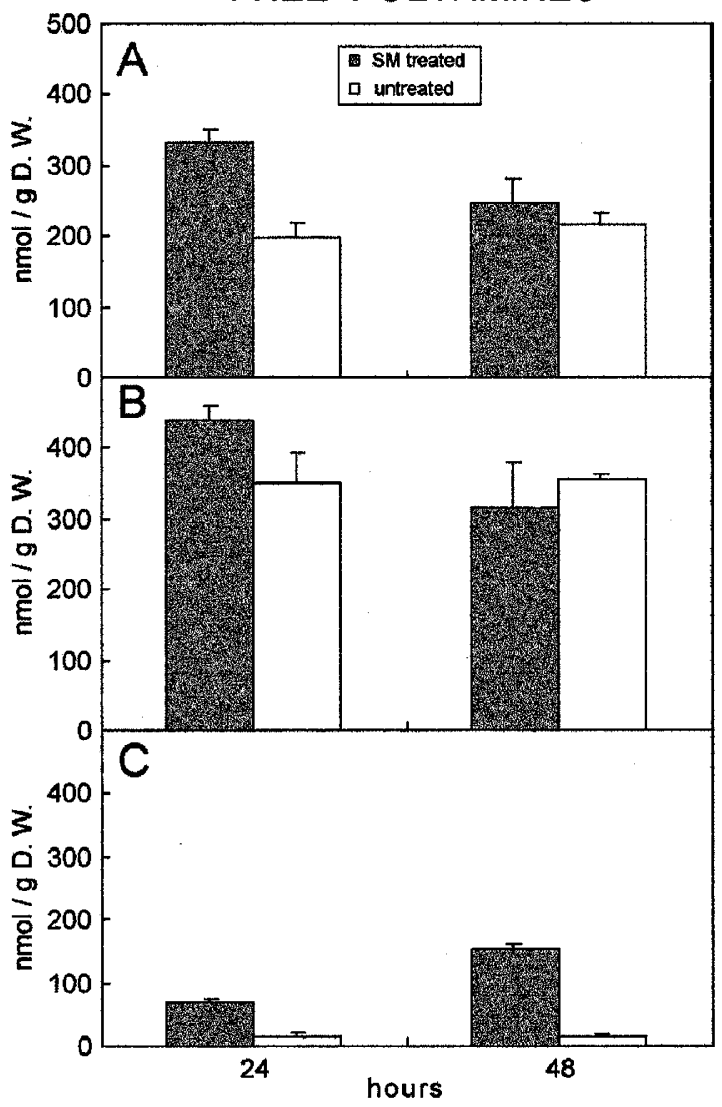

TCA-SOLUBLE POLYAMINES

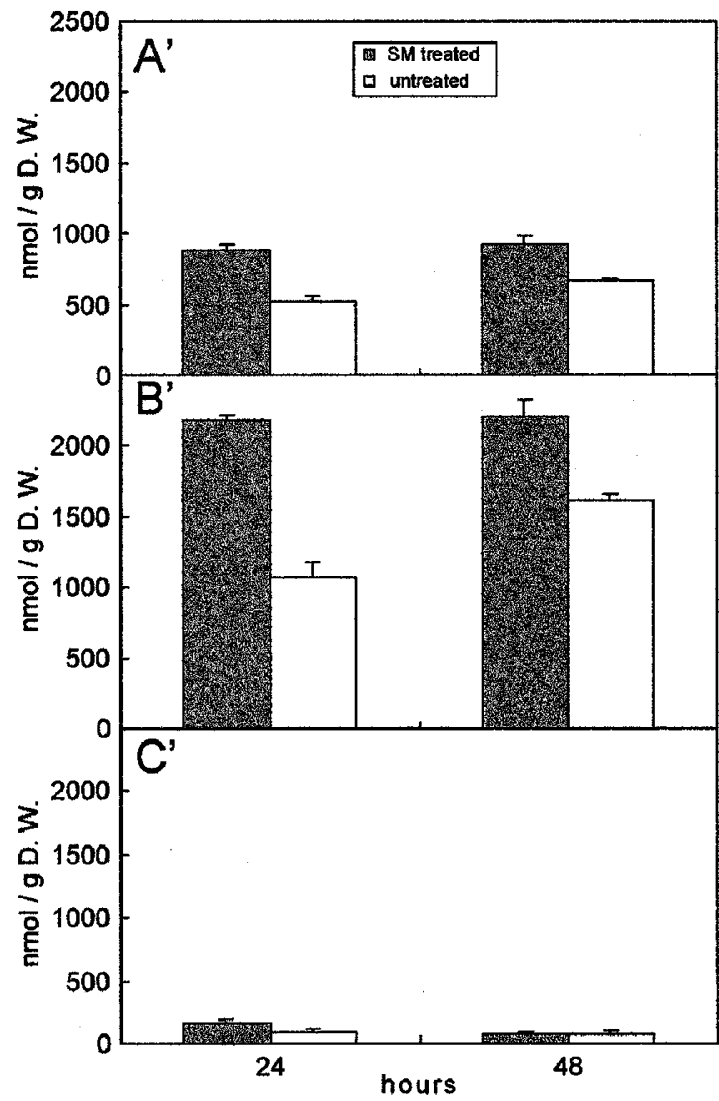

Figure 9 Content of free $(\mathbf{A}-\mathbf{C})$ and TCA-soluble conjugated $\left(\mathbf{A}^{\prime}, \mathbf{B}^{\prime}, \mathbf{C}^{\prime}\right)$ polyamines (nmol/g dry weight) in the corolla of flowers excised at stage 5. Flowers were either untreated or treated with $5 \mathrm{mM} \mathrm{SM}$ for the hours indicated. (A and $\left.\mathbf{A}^{\prime}\right)$ PU; (B and $\mathbf{B}^{\prime}$ ), SD; (C and $\left.\mathbf{C}^{\prime}\right)$, SM. The mean values of free PAs (PU at $24 \mathrm{~h}$; SM at 24 and $48 \mathrm{~h}$ ) and TCA-soluble PAs (SD at 24 and $48 \mathrm{~h} ; \mathrm{SM}$ at $24 \mathrm{~h}$ ) of samples treated with SM were significantly different (at least $P<0.05)$ from their untreated controls. Free SM and TCA-soluble SD significantly increased between 24 and $48 \mathrm{~h}$ in SM-treated samples and in untreated control respectively $(P<0.05)$

Also in isolated chloroplasts, exogenously supplied free $\mathrm{PU}$ and/or SD was metabolised in order to produce a definite mono-PU/bis-SD ratio. ${ }^{49}$ Mono- and bis-derivatives could play a different role. In fact, bis-PAs allow different proteins to cross-link with each other or to form intramolecular bridges of different lengths, depending on the size of the PAs involved, with an obvious structural consequence. Mono-PAs can affect the net charge of proteins, but it must be considered that the free charged amino group is very reactive and could even form non covalent linkages with other molecules. Mono-PAs can also be considered as intermediates for the formation of bisPAs, and thus their level depends on the rate of conjugation of a free PA to a glutaminyl residue and its further conjugation to another. Moreover, some mono-PAs are substrates of polyamine oxidases, and thus their levels can be regulated. ${ }^{18}$

As in mammals, ${ }^{14}$ the possibly multiple roles of TGase in tobacco PCD are difficult to establish. Useful information can be provided by studies on TGase localisation and type of substrates. Many cell structures and compartments are involved in the different stages of senescence and cell death in Nicotiana petals, i.e. cytoskeleton, cell walls, nuclei, chloroplasts and vacuoles. Subcellular compartmentation of plant TGases has been observed in Helianthus leaves and maize calli; ${ }^{27,50,51}$ in some compartments TGase could play a specific role. As suggested by the present data, the highest production of bis-derivatives, especially bis-PU, occurs in the phases of development and anthesis (stages 3-5) when the corolla changes shape in order to favour the pollination process. The cytoskeleton and cell walls may be responsible for this change of shape. In analogy with the animal cell, ${ }^{52}$ it is known that also in plants cytoskeletal proteins are targets for TGases, as shown during apical growth of pollen tubes, where actin and tubulin are modified by PAs. ${ }^{24}$

Starting from stage 6 when senescence begins, a relevant event takes place in the corolla, i.e. the modification of cell walls, as indicated by the appearance of autofluorescence, purported to be due to wall-bound phenolic substances. ${ }^{53}$ This process first affects those cells located in the most basal part of the corolla and then spreads to the entire organ. Recently, proteins located in the cell wall of the alga Chlamydomonas ${ }^{21}$ were reported to be substrates of TGase, but no information is available regarding higher plants. 


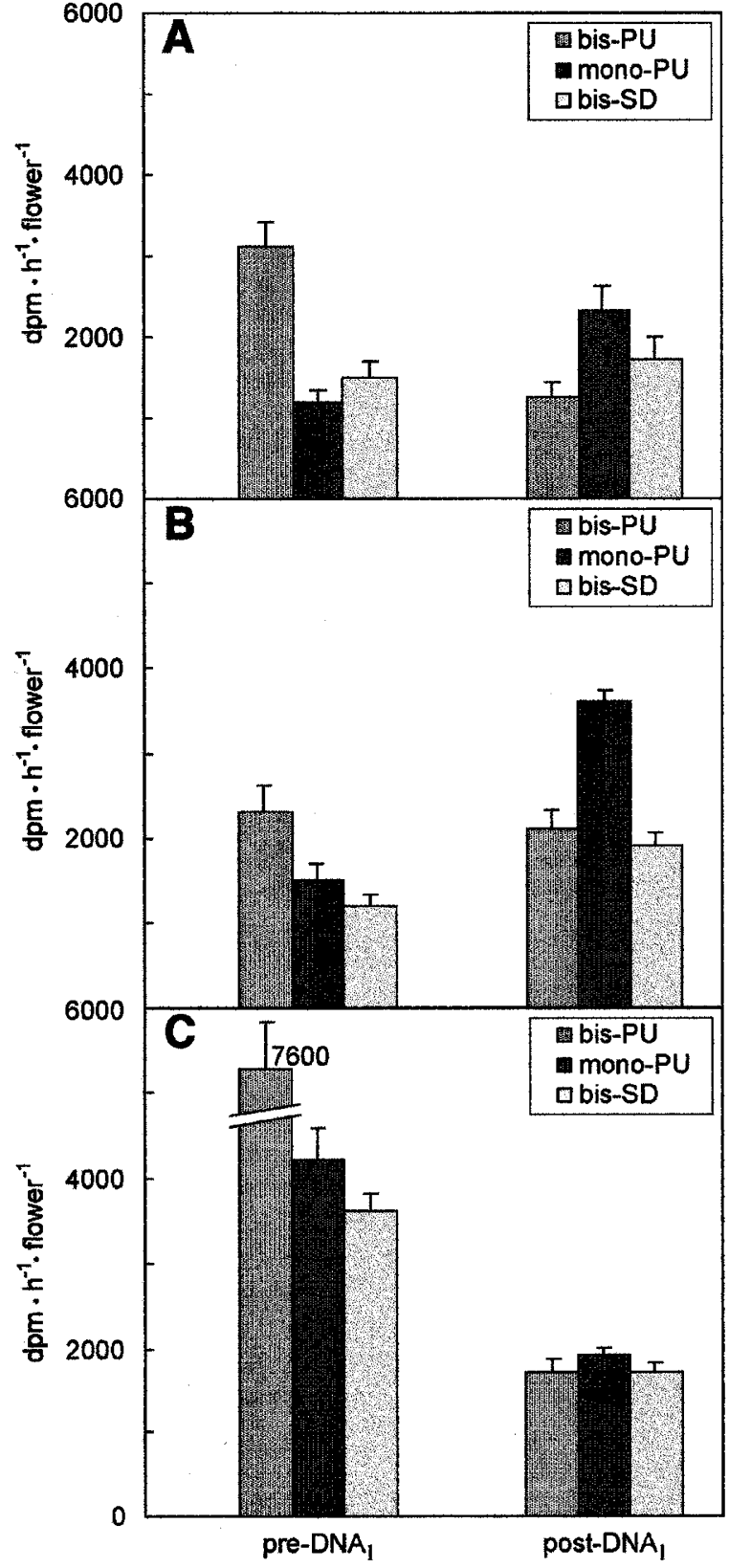

Figure 10 Transglutaminase activity (measured, on the basis of the Lorand assay, as amount of glutamyl-derivatives) of the corolla of flowers excised at stage 5 and untreated or treated with $5 \mathrm{mM} \mathrm{SM}$ or $0.25 \mathrm{mM}$ STS before (pre$\mathrm{DNA}_{\mathrm{l}}$ ) or after the DNA laddering (post-DNA $\mathrm{A}_{1}$ ). Labelled glutamyl-PAs (bis-PU, mono-PU, bis-SD) were detected by HPLC after incubation with $\left[{ }^{3} \mathrm{H}\right] \mathrm{PU}$ of the corolla extracts of flowers either untreated $(\mathbf{A})$ or treated with $5 \mathrm{mM} \mathrm{SM} \mathrm{(B)} \mathrm{or}$ $0.25 \mathrm{mM}$ STS (C). The mean values of samples before DNA laddering were significantly different (at least $P<0.05$ ) from the respective ones measured after DNA laddering as follows: mono-PU in all samples; bis-PU in untreated controls and in STS-treated ones; bis-SD only in STS-treated samples

Other relevant events occurring at first in the basal part at stage 6 and then throughout the corolla in the later stages of senescence are nuclear blebbing and DNA laddering. In mammal cells undergoing these nuclear events and apoptotic body formation, histones and $\operatorname{actin}^{16,52,54-56}$ are substrates of TGase.
Chloroplasts, present in the corolla especially in its early developmental stages, are very important as energy suppliers, and their functionality is dependent on chlorophyll content. The latter declined markedly between stages 5 and 6. Chloroplast TGases (ChITGases) are different from those of the cytoplasm and are active in chloroplasts of both higher and lower plants. ${ }^{20,27,51,57,58}$ Having as substrates the antenna complexes and Rubisco, ${ }^{26,27}$ they are possibly involved in photosynthesis. The decrease in total TGase activity during petal senescence could thus be partly related to the breakdown of chloroplasts. In leaves, chloroplast swelling, together with rupture of the tonoplast membrane, are signs of cell death. The latter also occurred in the corolla; it gradually increased with time, as indicated by the increase in conductivity and by the decrease in anthocyanin content after stage 6 .

A comparative analysis of the two parts of the corolla (at stages 6 and 7) showed that they were at different stages of senescence as also evidenced by the following: (a) protein content did not change in the proximal part between stages 6 and 7, whereas an evident decrease took place in the distal part; (b) proteases were more active in the distal part, concomitantly with the appearance of DNA laddering; (c) conjugated PAs were much higher in the proximal part than in the distal one.

In conclusion, in tobacco corollas, histologically similar but differently located cells are affected in succession by an endogenous programme of senescence and cell death involving their different compartments.

\section{Corolla of excised flowers}

Senescence, and thus cell death, was delayed by exogenously supplied SM (which was more efficient than PU or SD) and STS; the latter, however, exerted a more long-term effect. Both treatments caused a delay in DNA fragmentation, the prolonged maintenance of the pink colour of the corolla, indicative of delayed vacuole damage, as well as of chlorphyll content, suggesting that chloroplasts remained viable for a longer period of time. STS is a well-known antagonist of ethylene action. The idea that PAs also exert an anti-ethylene, and thus an anti-senescence action, has indeed been put forward, ${ }^{4}$ and inhibition of ethylene biosynthesis by PAs has been reported. ${ }^{41}$

Again, no clear correlation was found between total protein content and in vitro protease activity.

TGase activity was different in SM- or STS-treated flowers and in untreated controls. However, both in preand post-DNA laddering stages, the relative proportions of the three glutamyl-derivatives were similar in all three samples. Similarly to undetached flowers, bis-PU was the most abundant PA-derivative before the DNA laddering stage. Thereafter, bis-PU generally decreased and mono$\mathrm{PU}$ became the most abundant derivative. Thus, their levels appear to be related to the physiologial stage of flowers.

Data on the PA content of SM-treated flowers showed that this PA was taken up and converted through SD back to $\mathrm{PU}$, as previously observed in other plants. ${ }^{49,59}$ In addition to free PA, TCA-soluble conjugated SD and PU 
also accumulated under this treatment. Thus, the antisenescence effects exerted by SM could be due directly to free SM, to its free and/or TCA-soluble derivatives and/or its TGase-catalysed conjugates. TCA-soluble conjugated PAs constituted most of the total PA pool in tobacco flowers; these conjugates are mainly hydroxycinnamoyl amides. They are characteristic only of some plant families and are reported to increase in flowering and to be involved in reaction to pathogens. ${ }^{44}$ No evidence is reported that these conjugated PAs could be involved in senescence.

In animal systems the role of free PAs in apoptosis is still controversial. Prevention of apoptotic cell death by PAs was also observed in cultured cerebellar granule neurones. ${ }^{60}$ Similarly to the present data obtained in tobacco flower, the protective effect of supplied free PAs against PCD was observed by Brüne et al. $^{3}$ in thymocytes: SM, and to a lesser extent SD, but not PU, blocked DNA fragmentation and the onset of apoptosis, possibly by binding to DNA, as suggested by the authors. Also in higher plants, SD binds to DNA in vivo ${ }^{61}$ and in vitro ${ }^{62-64}$ by non-covalent interactions. By contrast, SM and SD are known to have an anti-nuclease and anti-protease action. ${ }^{65,66}$ More recently it was shown that SM inhibited dexamethasone-induced apoptosis upstream of caspase-9 activation. $^{67}$

Some papers describe an apoptosis-inducing effect of free PAs. In intestinal epithelial cells, depletion of SD and $\mathrm{SM}$, and accumulation of $\mathrm{PU}$ caused an increase of apoptosis, suggesting that normal levels of PA are necessary for PCD to occur within the usual time frame. ${ }^{68}$ An over-accumulation of SD caused hypercondensation of chromatin and internucleosomal cleavage. ${ }^{69} \mathrm{SM}$ also caused cytochrome $c$ exit from mitochondria and caspase activation in leukaemia cells and in a cell free system. ${ }^{70,71}$ In these systems, a 2-4-fold accumulation of free cytosolic PAs was responsible for the activation of the death programme. ${ }^{69,71}$ In senescent Nicotiana corollas supplied with SM, free PAs increased to a similar extent; however, differently from animal cells, plants can buffer against excess PAs by conjugating them to low molecular weight molecules (TCA-soluble conjugates) and compartment them in the vacuole. ${ }^{72}$ Thus, the different effects of free PAs on apoptosis could also depend on their real concentration in the cytoplasm and organelles. However the bound form could be responsible for these effects.

The possible roles of tTGase in apoptosis in animal cells have been recently reviewed by Melino and Piacentini, ${ }^{14}$ Griffin and Verderio, ${ }^{15}$ Chen and Metha ${ }^{16}$ and Fesus. ${ }^{17} \mathrm{~A}$ similar role for other TGases was described in many ageing mammalian systems. ${ }^{6,11}$ TGase could act as GTPase in early apoptotic events ${ }^{14}$ and also as stabiliser of specific proteins acting in its transamidating role; it polymerises proteins such as actin, annexin, vinculin, fibronectin, retinoblastoma protein, troponin, beta-tubulin, glutathione transferase $\mathrm{P} 1-1$, core ${ }^{54}$ and $\mathrm{H}^{56}$ histones. The latter are cleaved during apoptosis causing DNA laddering.

In plants there are no data about the possibility that TGase acts as a GTPase. The identification of proteins modified by PAs via transamidation in petals, which represent a good model of a genetically-based programme leading to $\mathrm{PCD},{ }^{36}$ will, in future, confirm if plants and animals share some of the basic mechanisms of PCD.

\section{Materials and Methods}

\section{Plant system}

Plants of Nicotiana tabacum L. (Solanaceae) cv Samsun were grown in the Orto Botanico of Bologna in pots in a growth chamber at a fixed temperature $\left(25^{\circ} \mathrm{C}\right)$ and light intensity $\left(10^{15}\right.$ quanta/ $\left.\mathrm{cm}^{2} \mathrm{~s}\right)$, and a photoperiod of $12 \mathrm{~h}$ light/dark. The developmental stages of the flowers were identified by corolla size, shape and colour. Whole corollas were collected at different developmental stages and analyzed cytologically and biochemically (pigments, water and protein content, conductivity, DNA fragmentation, protease and TGase activities). Experiments were also performed by cutting flowers at anthesis at the base of the pedicel and immersing them in different solutions of PU, SD and SM for different lengths of time. Labelled SM, N,N'-bis-(3-aminopropyl)-([1,4- $\left.{ }^{14} \mathrm{C}\right]$ tetramethylene-1,4-diamine) (4.07 $\mathrm{GBq} / \mathrm{mmol}$; Amersham Pharmacia Biotech., UK), was added as a tracer to measure SM conjugation. As a control, untreated flowers and flowers treated with $0.25 \mathrm{mM}$ STS were used.

\section{Conductivity}

Conductivity measurement was performed by means of a conductimeter according to Mittler et al. ${ }^{73}$ Petals were immersed in $40 \mathrm{ml}$ of distilled water whose conductivity was measured at 0 time and after $3 \mathrm{~h}$. Results are expressed as percentage increase relative to the lowest value measured, i.e. at stage $3 / 4$.

\section{Water}

Water content was determined by measuring fresh and dry weights and expressed as the percentage of water on total fresh weight. Dry weight was determined after drying petals in a stove at $110^{\circ} \mathrm{C}$ until no further change in weight was observed.

\section{Pigments}

Pigments were extracted by soaking petals in $3 \mathrm{ml}$ methanol- $\mathrm{HCl} 1 \%$ for $1 \mathrm{~h}$. Anthocyanin content was determined on the clarified supernatant by absorbance measurement according to the formula: $A_{530}-0.25 \times A_{657}$ that corrects absorbance for chlorophyll degradation products. ${ }^{74} A_{657}$ was used to evaluate chlorophyll content as phaeophytin.

\section{DNA fragmentation}

DNA extraction was performed using the QIAGEN Dneasy Plant Minikit, according to the manufacturer's instructions. DNA $(2-5 \mu \mathrm{g})$ was loaded on $1.4 \%$ agarose gels which were stained with ethydium bromide before migration.

\section{Protein extraction}

Corollas were homogenised in 1:2 (w/v) $50 \mathrm{mM}$ Tris- $\mathrm{HCl} \mathrm{pH} 8$ containing $2 \mathrm{mM}$ DTT and then centrifuged at $1500 \times \mathrm{g}$; the supernatants were used for protein determination or enzyme assays. Proteins were extracted both at $\mathrm{pH} 8$ and 5.5 and their amount determined by the method of Lowry et al. ${ }^{75}$ using bovine serum 
albumin as standard. All chemicals were purchased from Sigma, Aldrich (Milano, Italy).

\section{Protease activity}

Protease activity was determined by the azo-casein method. ${ }^{76}$ Samples (about $200 \mathrm{mg}$ ) were homogenised in five volumes of $250 \mathrm{mM}$ sodium citrate buffer $\mathrm{pH} 5$ (optimal $\mathrm{pH}$ as determined by assaying in the $\mathrm{pH} 3-8$ range) containing $2 \mathrm{mM}$ 2-mercaptoethanol and centrifuged $30 \mathrm{~min}$ at $13250 \times \mathrm{g}$. Each assay mixture contained: $270 \mu \mathrm{l}$ buffer, $150 \mu \mathrm{l}$ azo-casein ( $10 \mathrm{mg} / \mathrm{ml}$ aqueous solution), $80 \mu \mathrm{l}$ sample or buffer. The reaction was immediately stopped in half of the samples by adding $900 \mu \mathrm{l} 10 \% \mathrm{TCA}\left(\mathrm{T}_{0}\right)$. The other samples were incubated for $3 \mathrm{~h}\left(\mathrm{~T}_{3}\right)$ at $37^{\circ} \mathrm{C}$, stopped as above and kept for $45 \mathrm{~min}$ at $4^{\circ} \mathrm{C}$. Protease activity was evaluated as the $\Delta \mathrm{A}_{366}$ (difference between optical densities of the samples $T_{3}$ and $T_{0}$ ). Activity was measured in the presence or absence of $1 \mathrm{mM}$ PMSF or $0.1 \mathrm{mM}$ leupeptin. ${ }^{76}$

\section{Transglutaminase assay}

Corollas were extracted in $100 \mathrm{mM}$ Tris $-\mathrm{HCl} \mathrm{pH} 8$ containing $2 \mathrm{mM}$ DTT, $0.5 \%$ Triton X-100 and $15 \mathrm{mM}$ 2-mercaptoethanol. The extract was centrifuged at $500 \times g$ for $10 \mathrm{~min}$. The in vitro assay was performed on the basis of the method of Lorand et al. ${ }^{77}$ modified as follows. The incubation mixture, whose final $\mathrm{pH}$ was 7.7 , included: $100 \mu \mathrm{l}$ supernatant (containing about $600-700 \mu \mathrm{g}$ total proteins), $200 \mu \mathrm{l} 100 \mathrm{mM}$ $\mathrm{pH} 8.5$ Tris buffer and final concentrations of the following: $0.2 \mathrm{mM}$ putrescine (PU), $3 \mathrm{mM}$ 2-mercaptoethanol and $5 \mathrm{mM} \mathrm{CaCl} 2$. As radioactive tracer $222 \mathrm{kBq}\left[1,4(\mathrm{n})-{ }^{3} \mathrm{H}\right] \mathrm{PU}(0.55 \mathrm{TBq} / \mathrm{mmol}$; Amersham Pharmacia Biotech., UK) was supplied to the assay mixture. In some experiments different concentrations of $\mathrm{CaCl}_{2}$ were added to the assay mixture together $1 \mathrm{mM}$ EGTA according to Lilley et al. ${ }^{19}$ Different concentrations of EGTA, pre-incubated for $10 \mathrm{~min}$, were also assayed. After $60 \mathrm{~min}$ of incubation at $30^{\circ} \mathrm{C}$, the reaction was stopped with $5 \%$ (w/v final concentration) TCA also containing $2 \mathrm{mM}$ unlabelled PU in order to remove trapped free polyamines. The mixture was stored at $4^{\circ} \mathrm{C}$ for $24 \mathrm{~h}$ and then centrifuged at $13250 \times g$ for $10 \mathrm{~min}$. Pellets were solubilised with $\mathrm{NaOH}$ at $37^{\circ} \mathrm{C}$ and then precipitated twice with $5 \%$ TCA. An aliquot of the final solubilised pellet was dissolved in Ultima Gold (Canberra Packard, Milano, Italy) scintillation cocktail and radioactvity counted in a Beckman LS 6500 scintillation counter.

\section{Polyamine derivatives}

The solubilised pellet, washed with anhydrous ethyl ether, was proteolytically digested as described by Folk et al. ${ }^{78}$ Ion exchange chromatographic separation of $\gamma$-glutamyl polyamines in the acidinsoluble fraction was performed on a Jasco HPLC, equipped with a $4.5 \times 90 \mathrm{~mm}$ column packed with Ultropack 8 resin $\left(\mathrm{Na}^{+}\right.$form), using the five-buffer system previously reported. ${ }^{49,78}$ The identity of conjugated polyamines ( $\gamma$-glutamyl-polyamines) was determined after releasing free polyamines by acid hydrolysis of the ion-exchange chromatographic fractions corresponding to the predicted retention times.

\section{Polyamine determination}

Polyamines were determined by HPLC after extraction with $4 \%$ TCA and dansylation as described by Torrigiani et al. ${ }^{79}$

\section{Light microscopy}

The epidermis of the corolla at different stages of growth was peeled off with fine forceps and immediately observed under a UV Zeiss
Axiophot microscope equipped with a Zeiss UV-H 436 (BP 436/10, FT 460, LP 470) filter. The same samples were stained with a solution of DAPI $(1 \mathrm{mg} / \mathrm{ml})$ in $0.05 \mathrm{M}$ phosphate buffer $\mathrm{pH} 5.8$ and observed under UV light at $365 \mathrm{~nm}$ using a Zeiss filter UV-H 365 (BP 365/12, FT 395, LP 397). Alternatively, the sections were stained with toluidine blue and observed under white light.

All experiments were performed separately on at least five different corollas at the same stage, and repeated at least once. All values are means with standard errors. Student's $t$-test was used to evaluate the correlation coefficient $(r)$ of the curves, and to compare means as reported in the legends.

\section{Acknowledgements}

This work was supported by the University of Bologna (Funds for Selected Research Topics, Special Project 'Apoptosis' to D SerafiniFracassini).

\section{References}

1. Suttle JC (1981) Effect of polyamines on ethylene production. Phytochem. 20: $1477-1480$

2. Matthews HR (1993) Polyamines, chromatin structure and transcription. BioAssays 15: 561-566

3. Brüne B, Hartzell P, Nicotera P and Orrenius S (1991) Spermine prevents endonuclease activation and apoptosis in thymocytes. Exp. Cell Res. 195:323329

4. Galston AW and Kaur-Sawhney R (1987) Polyamines and senescence in plants. In Plant senescence: its biochemistry and physiology, Thomson WW, Nothnagel EA, Huffaker RC eds (Rockville MD: American Society of Plant Physiologists) pp. $167-181$

5. Cordella-Miele E, Miele L and Mukherjee AB (1990) A novel transglutaminasemediated post-translational modification of phospholipase A2 dramatically increases its catalytic activity. J. Biol. Chem. 265: 17180-17188

6. Lorand L and Conrad SM (1984) Transglutaminases. Mol. Cell. Biochem. 58: 935

7. Grandi B, Del Duca S, Serafini-Fracassini D and Dinnella C (1992) Re-entry in cell cycle: protein metabolism and transglutaminase-like activity in Helianthus tuberosus. Plant Physiol. Biochem. 30: 415-424

8. Del Duca S, Allué Creus J, D'Orazi D, Dondini L, Bregoli AM and SerafiniFracassini D (2000) Tuber vegetative stages and cell cycle in Helianthus tuberosus: protein pattern and their modification by spermidine. J. Plant. Physiol. 156: $17-25$

9. Fesus L, Thomazy V and Falus A (1987) Induction and activation of tissue transglutaminase during programmed cell death. FEBS Lett. 224: 104-108

10. Fesus L, Thomazy V, Autuori F, Cerù MP, Tarcsa E and Piancentini M (1989) Apoptotic hepatocytes become insoluble in detergent and chaotropic agents as a result of transglutaminase action. FEBS Lett. 245: 150-154

11. Aeschlimann D and Paulsson M (1994) Transglutaminases: protein crosslinking enzymes in tissues and body fluids. Thromb. Haemost., 71: 402-415

12. Fesus $L$ and Thomazy $V$ (1988) Searching for the function of tissue transglutaminase: its possible involvement in the biochemical pathway of programmed cell death. Adv. Exp. Med. Biol. 231: 119-134

13. Piacentini M, Davies PJA and Fesus L (1994) The molecular basis of apoptosis in disease. In Apoptosis II Tomei LD and Cope FO, eds (Cold Spring Harbor, NY: Curr Comm Cell Mol. Biol. Cold Spring Harbor Laboratory Press) pp. 143-164

14. Melino $G$ and Piacentini M (1998) Tissue transglutaminase in cell death: a downstream or a multifunctional upstream effector? FEBS Lett. 245: 150-154

15. Griffin $M$ and Verderio $E(2000)$ Tissue transglutaminase in cell death. In Programmed cell death in aminals and plants, Bryant JA, Hughes SG and Garland JM, eds (Oxford: BIOS Scientific Publ. Lmt) pp. 223-241

16. Chen SK and Metha K (1999) Tissue transglutaminase: an enzyme with a split personality. Int. J. Biochem. Cell Biol. 31: 817-836 
17. Fesus $L$ (1999) Inducible gene expression in apoptosis. Cell Death Differ. 6: $1144-1145$

18. Serafini-Fracassini D, Del Duca S and Beninati S (1995) Plant transglutaminases. Phytochemistry 40: 355-365

19. Lilley G, Skill J, Griffin M and Bonner P (1998) Detection of $\mathrm{Ca}^{2+}$-dependent transglutaminase activity in root and leaf tissue of monocotyledonous and dicotyledonous plants. Plant Physiol. 117: 1115-1123

20. Kang H and Cho YD (1996) Purification and properties of transglutaminase from soybean (Glycine max) leaves. Biochem. Biophys. Res. Commun. 223: $288-$ 292

21. Waffenschmidt S, Kusch T and Woessner JP (1999) A transglutaminase immunologically related to tissue transglutaminase catalyzes cross-linking of cell wall proteins in Chlamydomonas reinhardtii. Plant Physiol. 121: 1003-1015

22. Serafini-Fracassini D, Del Duca S and D'Orazi D (1988) First evidence for polyamine conjugation mediated by an enzymic activity in plants. Plant Physiol. 87: $757-761$

23. Serafini-FracassiniD, DelDuca S and Torrigiani P (1989) Polyamine conjugation during the cell cycle of Helianthus tuberosus: non enzymatic and transglutaminase-like binding activity. Plant Physiol. Biochem. 27: 659-668

24. Del Duca S, Bregoli AM, Bergamini C and Serafini-Fracassini D (1997) Transglutaminase-catalyzed modification of cytoskeletal proteins by polyamines during the germination of Malus domestica pollen. Sex. Plant Reprod. 10 $89-95$

25. Dondini L, Bonazzi S, Del Duca S, Bregoli AM and Serafini-Fracassini D (2001) Acclimation of chloroplast transglutaminase to high $\mathrm{NaCl}$ concentration in a polyamine-deficient variant strain of Dunaliella salina and in its wild type. J. Plant Physiol. 158: 185-197

26. Margosiak SA, Dcharma A, Bruce-Carver MR, Gonzales AP, Louie D and Kuehn GD (1990) Identification of the large subunit of ribulose 1,5-bisphosphate carboxylase/oxygenase as a substrate for transglutaminase in Medicago sativa L. (Alfalfa). Plant Physiol. 92: 88-96

27. Del Duca S, Tidu V, Bassi R, Serafini-Fracassini D and Esposito C (1994) Identification of transglutaminase activity and its substrates in isolated chloroplast of Helianthus tuberosus. Planta 193: 283-289

28. Votyakova TV, Wallace HM, Dunbar B and Wilson SB (1999) The covalent attachment of polyamines to proteins in plant mitochondria. Eur. J. Biochem. 260: $250-257$

29. Greenberg JT (1996) Programmed cell death: a way of the life for plants. Proc. Natl. Acad. Sci. USA 93: 12094-12097

30. Wang H, Li J, Bostok RM and Gilchrist DG (1996) Apoptosis: a function paradigm for programmed plant cell death induced by a host-selective phytotoxin and invoked during development. Plant Cell 8: 375-391

31. Ryerson DE and Heath MC (1996) Cleavage of nuclear DNA into nucleosoma fragments during cell death induced by fungal infection or by abiotic treatments. Plant Cell 8: 393-402

32. Mittler R and Lam E (1995) Identification, characterization and purification of tobacco endonuclease activity induced upon hypersensitive response cell death. Plant Cell 7: 1951-1962

33. Ori N, Juarez MT, Jackson D, Yamaguchi J, Banowetz GM and Hake S (1999) Leaf senescence is delayed in tobacco plants expressing the maize homeobox gene knotted 1 under the control of a senescence-activated promoter. Plant Cel 11: $1073-1080$

34. Orzaez D and Granell A (1997) DNA fragmentation is regulated by ethylene during carpel senescence in Pisum sativum. Plant J. 11: 137-144

35. Panavas T, Reid PD and Rubinstein B (1998) Programmed cell death of daylily petals: activities of wall-based enzymes and effects of heat shock. Plant Physiol. Biochem. 36: $379-388$

36. Rubinstein B (2000) Regulation of cell death in flower petals. Plant Mol. Biol. 44: $303-318$

37. Orzaez D, Blay R and Granell A (1999) Programme of senescence in petals and carpels of Pisum sativumL. flowers and its control by ethylene. Planta 208:220 226

38. Whitehead CS, Halevy AH and Reid MS (1984) Roles of ethylene and 1aminocyclopropane-1-carboxylic acid in pollination and wound-induced senescence of Petunia hybrida flowers. Physiol. Plant. 61: 643-648

39. Woltering EJ, Somhorst D and Van der Veer P (1995) The role of ethylene in interorgan signalling during flower senescence. Plant Physiol. 109: 1219-1225
40. Orzaez D and Granell A (1997) The plant homologue of the defender against apoptotic death gene is down-regulated during senescence of flower petals. FEBS Lett. 404: 275-278

41. Lee MM, Lee SH and ParkK (1997) Effects of spermine on ethylene biosynthesis in cut carnation (Dianthus caryophyllus L.) flowers during senescence. J. Plant Physiol., 151: 68-73

42. Hill SE, Stead AD and Nichols R (1987) Pollination-induced ethylene and production of 1-aminocyclopropane-1-carboxylic acid by pollen of Nicotiana tabacum cv. White Burley. J Plant Growth Regul. 6: 1-13

43. Woltering EJ and Van Doorn WG (1988) Role of ethylene in senescence of petals-morphologic and taxonomic relationships. J. Exp. Bot. 39: 1605-1616

44. Martin-Tanguy J (1996) Flowering, polyamines, inhibitors of polyamine and ethylene biosynthesis. Flowering Newslett. 21: 10-20

45. Lam E and delPozo O (2000) Caspase-like protease involvement in the control of plant cell death. Plant Mol. Biol. 44: 417-428

46. Solomon M, Belenghi B, Delle Donne M, Menachem E and Levine A (1999) The involvement of cysteine proteases and protease inhibitor genes in the regulation of programmed cell death in plants. Plant Cell 11: $431-443$

47. Kortouth HAAJ, Berecki G, Bruin W, van Duijn B and Wang M (2000) The presence and subcellular localization of caspase 3 -like proteinases in plant cells. FEBS Lett. 475: $139-144$

48. Fabbi M, Malimpietri D, Martini S, Brancolini C, Amoresano A, Scaloni A, Bargellesi A and Cosulich E (1999) Tissue transglutaminase is a caspase substrate during apoptosis. Cleavage causes loss of transamidating function and is a biochemical marker of caspase 3 activation. Cell Death Differ. 6: 992 1001

49. Del Duca S, Beninati S and Serafini-Fracassini D (1995) Polyamines in chloroplasts: identification of their glutamyl- and acetyl-derivatives. Biochem. J. 305: $233-237$

50. Falcone P, Serafini Fracassini D and Del Duca S (1993) Comparative studies of transglutaminase-like activity and substrates in different organs of Helianthus tuberosus. J. Plant Physiol. 142: 265-273

51. BernetE, Claparols I, Dondini L, Santos MA, Serafini-Fracassini D and Torné JM (1999) Changes in polyamine content, arginine and ornithine decarboxylases and transglutaminase activities during light/dark phases of initial differentiation in maize calluses and their chloroplasts. Plant Physiol. Biochem. 37: 899-909

52. Nemes Z, Adany R, Balazs M, Boross P and Fesus L (1997) Identification of cytoplasmic actin as an abundant glutaminyl substrate for tissue transglutaminase in HL-60 and U937 cells undergoing apoptosis. J. Biol. Chem. 272:2057720583

53. Heath MC (1984) Relationship between heat-induced fungal death and plant necrosis in compatible and incompatible interactions involving the bean and cowpea rust fungi. Phytopatol. 61: 383-388

54. Ballestar E, Abad C and Franco L (1996) Core histones are glutaminyl substrates for tissue transglutaminase. J. Biol. Chem. 271: 18817-18824

55. Dini L, Coppola S, Ruzittu MT and Ghibelli L (1996) Multiple pathways for apoptotic nuclear fragmentation. Exp. Cell Res. 223: 340-347

56. Cooper AJ, Wang J, Pasternack R, Fuchsbauer HL, Sheu RK and Blass JP (2000) Lysine-rich histone $(\mathrm{H} 1)$ is a lysyl substrate of tissue transglutaminase: possible involvement of transglutaminase in the formation of nuclear aggregates in $(C A G)(n) / Q(n)$ expansion diseases. Dev. Neurosci. 22: 404-417

57. Dondini L, Bonazzi S and Serafini-Fracassini D (2000) Recovery of growth capacity and of chloroplast transglutaminase activity induced by polyamines in a polyamine-deficient variant strain of Dunaliella salina. J. Plant Physiol. 157: $473-480$

58. Signorini M, Beninati S and Bergamini C (1991) Identification of transglutaminase activity in the leaves of Silver Beet (Beta vulgaris L.). J. Plant Physiol. 137: $547-552$

59. Bagni N (1967) Absorption of spermine and spermidine and their degradation in explants of Helianthus tuberosus in vitro. Z. Pflanzenphysiol. 57: 22-24

60. Harada J and Sugimoto M (1997) Polyamines prevent apoptotic CD in cultured cerebellar granule neurons. Brain Res. 753: 251-259

61. Bagni N, Corsini E and Serafini-Fracassini D (1971) Growth-factors and nucleic acid synthesis in Helianthus tuberosus. Reversal of actinomycin D inhibition by spermidine. Physiol. Plant. 24: 112-117 
62. D'Orazi D, Serafini-Fracassini D and Bagni N (1979) Polyamine effect on the stability of DNA-actinomycin D complex. Biochem. Biophys. Res. Commun. 90: $362-367$

63. Liquori AM, Constantino L, Crescenzi V, Elia V, Giglio E, Puliti R, De SantisSavino M and Vitagliano V (1967) Complexes between DNA and polyamines: a molecular model. J. Mol. Biol. 24: 113-122

64. Feuerstein BG, Williams LD, Basu MS and Marton LJ (1991) Implications and concepts of polyamine-nucleic acid interactions. J. Cell Biochem. 46: 37-47

65. Kaur-Sawhney R, Altman A and Galston AW (1978) Dual mechanisms in polyamine-mediated control of ribonuclease activity in oat leaf protoplasts. Plant Physiol. 62: 158-160

66. Balestreri E, Cioni P, Romagnoli A, Bernini S, Fissi A and Felicioli R (1987) Mechanism of polyamine inhibition of a leaf protease. Arch. Biochem. Biophys. 255: $460-463$

67. Hegardt C, Andersson G and Oredsson S (2001) Different roles of spermine in glucocorticoid- and Fas-induced apoptosis. Exp. Cell Res. 266: 333-341

68. Ray RM, Viar MJ, Yuan Q and Johnson LR (2000) Polyamine depletion delays apoptosis of rat intestinal epithelial cells. Am. J. Physiol. Cell Physiol. 278: C480-C489

69. Poulin R, Pelletier G and Pegg AE (1995) Induction of apoptosis by excessive polyamine accumulation in ornithine decarboxylase-overproducing $\mathrm{L} 1210$ cells. Biochem. J. 311: 723-727

70. Stefanelli C, Bonavita F, Stanic I, Mignani M, Facchini A, Pignatti C, Flamigni F and Caldarera CM (1998) Spermine causes caspase activation in leukaemia cells. FEBS Lett. 437: $233-236$
71. Stefanelli C, Bonavita F, Stanic I, Pignatti C, Flamigni F, Guarnieri C and Caldarera CM (1999) Spermine triggers the activation of caspase-3 in a cell-free model of apoptosis. FEBS Lett. 451: 95-98

72. Pistocchi R, Keller F, Bagni N and Matile P (1988) Transport and subcellular localization of polyamines in carrot protoplasts and vacuoles. Plant Physiol. 87: $514-518$

73. Mittler R, Shulaev V, Seskar M and Lam E (1996) Inhibition of programmed cell death in tobacco plants during a pathogen-induced hypersensitive response at low oxygen pressure. Plant Cell 8: 1991-2001

74. Weiss D and Halevy AH (1989) Stamens, GA, pigmentation and growth of petunia corollas. Planta 179: 89-96

75. Lowry OH, Rosebrough NJ, Farr AL and Randall RJ(1951)Protein measurement with the Folin phenol reagent. J. Biol. Chem. 193: 265-275

76. Fritz H, Tautschold I and Werle E (1974) Protease inhibitors. In Methods of enzymic analysis, Bergmayer HU ed (New York: Verlag Chemie Weinheim Acad. Press) Vol.2, pp. 1064-1080

77. Lorand L, Campbell-Wilkes LK and Cooperstein L (1972) Filter paper assay for transamidating enzymes using radioactive amine substrates. Anal. Biochem. 50: 623-631

78. Folk JE, Park MH, Chung SI, Schrode J, Lester EP and Cooper HL (1980) Polyamines as physiological substrates for transglutaminases. J. Biol. Chem. 255: $3695-3700$

79. Torrigiani P, Rabiti AL, Betti L, Marani F, Brizzi M, Bagni N and Canova A (1995) Improved method for polyamine determination in TMV, a rod-shaped virus. J. Virol. Methods. 53: 157-163 